\title{
Potential Benefits of Introducing Integrated Solid Waste Management Approach in Developing Countries: A Case Study in Kathmandu City
}

\author{
Rajeev K. Singh ${ }^{1}$, Helmut Yabar $^{2,3}$, Takeshi Mizunoya ${ }^{2,3}$, Yoshiro Higano ${ }^{2,3}$ \& Randeep Rakwal ${ }^{4,5}$ \\ ${ }^{1}$ Graduate School of Life and Environmental Sciences, University of Tsukuba, Tsukuba, Ibaraki, Japan \\ ${ }^{2}$ Faculty of Life and Environmental Sciences, University of Tsukuba, Tsukuba, Ibaraki, Japan \\ ${ }^{3}$ Laboratory of Social Environmental System, University of Tsukuba, Tsukuba, Ibaraki, Japan \\ ${ }^{4}$ Organization for Educational Initiatives, University of Tsukuba, Tsukuba, Ibaraki, Japan \\ ${ }^{5}$ Research Laboratory for Biotechnology and Biochemistry (RLABB), Kathmandu, Nepal \\ Correspondence: Rajeev Kumar Singh, Graduate School of Life and Environmental Sciences, University of \\ Tsukuba, 1-1-1 Tennoudai, Tsukuba, Ibaraki 305-8572, Japan. Tel: 81-29-853-4747. E-mail: \\ tsukubaraj@gmail.com
}

Received: September 10, 2014 Accepted: September 22, 2014 Online Published: November 4, 2014

doi:10.5539/jsd.v7n6p70 URL: http://dx.doi.org/10.5539/jsd.v7n6p70

\begin{abstract}
Rapid economic and population growth experienced in last decade has brought significant increase in amount of urban waste generation in many developing countries like Nepal. Increasing waste generation created many problems including littering and dumping in and around outskirts of urban areas. Main problems associated with waste management in most developing countries are 1) low waste collection rates, 2) low recycling levels (recycling limited to informal recyclers), 3) littering, and 4) inappropriate final disposal. In addition to urban environmental pollution, inappropriate disposal causes generation of Greenhouse gasses such as methane gas and leachates from landfill sites. It is emphasized that most recycling is done by informal sector, restricted to materials having high market value like metals, paper and plastics. Here, we identify the potential environmental and socio-economic benefits of introducing organic waste recovery coupled with expansion of recycling of inorganic waste through cooperation with informal sector and establishment of a well-designed and managed sanitary landfill. Kathmandu city was used as a model case and Life Cycle Assessment tool was applied for evaluating potential environmental impacts. Four different scenarios were proposed based on feasible options that focus on organic recovery and informal recycling at transfer station prior to movement to landfill site. Scenarios were evaluated in terms of Global Warming Potential, Biochemical Oxygen Demand, final disposal waste, and recycling levels and energy recovery. We suggest that introduction of bio-gasification of commercial waste and composting of household waste coupled with enhanced recycling and sanitary landfill might provide highest environmental and socio-economic benefits.
\end{abstract}

Keywords: Kathmandu city, life cycle assessment, waste management, organic waste, sanitary landfill

\section{Introduction}

\subsection{Urban Waste Management Challenges for Cities in Developing Countries: The Case of Kathmandu City}

Waste management is one of the biggest challenges in developing countries due to increasing population, rapid urbanization (i.e. changing lifestyle patterns) and industrialization (Guerrero, Mass \& Hogland, 2013, Yabar, Hara, Uwasu, Yamaguchi, \& Zhang, 2009). Developing Asian countries like China, India, Indonesia, Vietnam, and Cambodia have serious environmental contamination due to large amounts of municipal waste being dumped into open dumping sites on a daily basis without adequate management (Eguchi et al., 2013). Kathmandu, the capital city of Nepal (Fig. 1) is also experiencing rapid population growth, causing a fast increase in waste generation that cannot be properly addressed by the local government. Primarily, Kathmandu is facing a significant problem in solid waste management including collection, transfer and final disposal of waste coupled with a lack of public awareness of the solid waste system, haphazard urbanization, introduction of environmental hazardous materials in the waste stream and changing consumer consumptions patterns (Alam, Chowdhury, Hasan, Karanjit, \& Shrestha, 2008). Thus, Kathmandu Metropolitan city (KMC) requires renewed attention for effective management of its waste. Although this problem is serious there are only few studies on 
waste management in KMC.

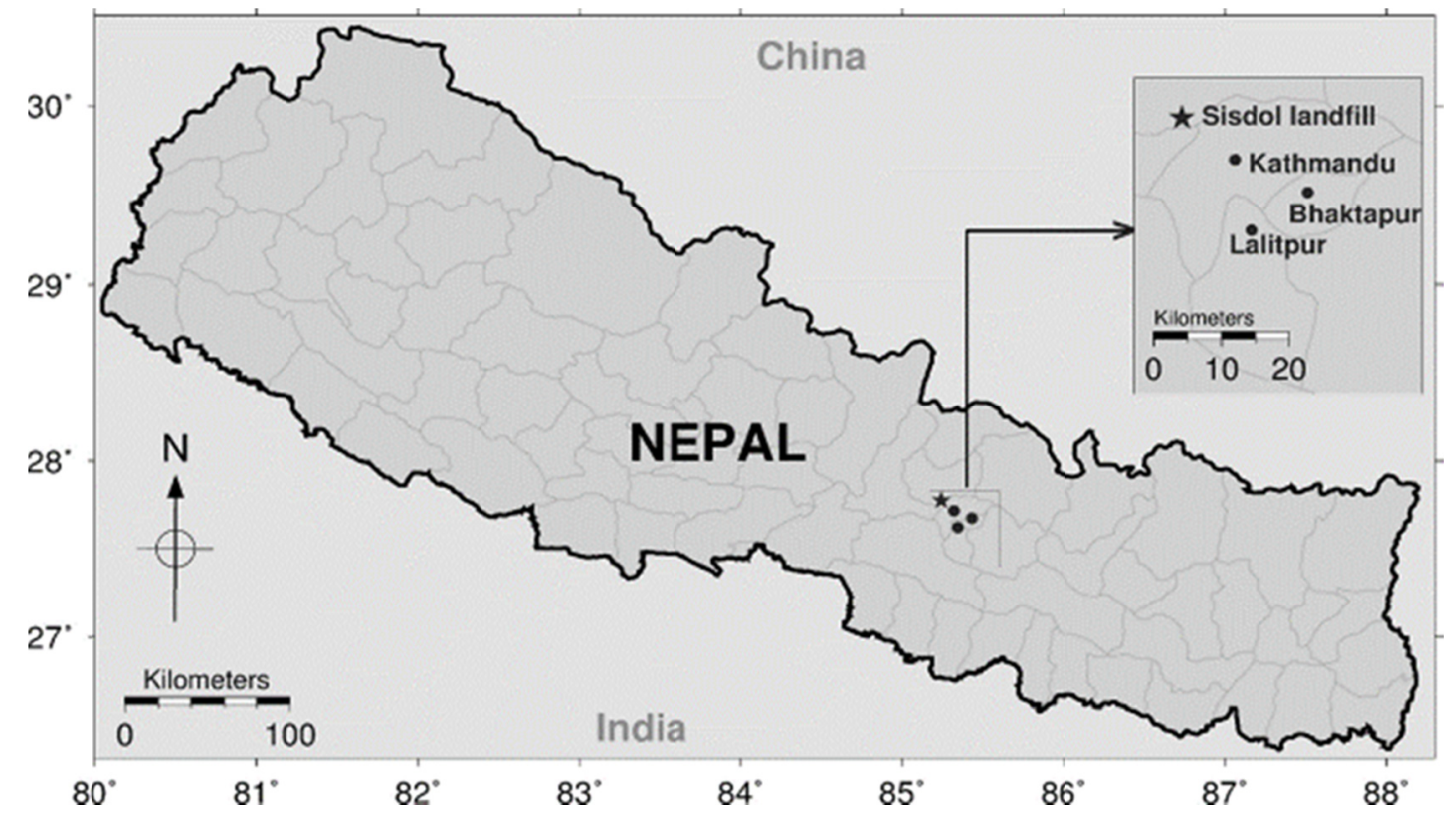

Figure 1. Map of Nepal, and the location of Kathmandu city

For example, Joshi (2013) proposed a need for sanitary landfill site and biological treatment of organic waste whereas Sapkota (2013) suggested that rather than planning for such a facility, it is important that research provides holistic solution to the problem. Before searching for holistic solutions, the immediate answer that can be addressed is on the treatment of organic waste (developing countries have higher levels of this waste). The separation of organic waste at the source provides additional advantages, in the sense that it can be further taken for biological treatment and thereafter utilized for the production of energy and compost. The recovery of organic waste by composting and bio-gasification has both environmental and socio economic benefits (UNEP, 2013). The treatment of organic wastes (that accounts for more than $60 \%$ of the total waste in developing countries) will not only lessen the burden of waste transportation and final disposal but will also have a significant impact on Greenhouse gas (GHG) emission reduction.

\subsection{Past and Present Situation of Waste Management in KMC}

In the past, the low waste generation was associated with the treatment of waste at home. Being mostly organic, the waste was mainly used to make compost in-house using home compost bins called "saagas" while the remainder was reused and recycled. With increase in the waste generation due to increasing population and economic growth, waste management became difficult resulting in dumping some waste along the Bagmati River (Rana, 2003). Waste management became such an issue that the German Society for International Cooperation (GTZ) Solid Waste Management Project was established in 1981 with technical and financial support from the GTZ (Anderzen \& Blees, 2003). This project constructed the Gokarna landfill site, which began operations in 1986 (Rana, 2003). The Teku transfer station and composting plant also opened in the same year (Rana, 2003). GTZ also constructed a compost plant which included a waste sorting line to produce good quality compost. However, this plant was unable to separate glass and it eventually closed in 1992 (Anderzen \& Blees, 2003). Although there were informal recyclers (around 100) at the Teku transfer station who separated the organic from material waste, their demands for better conditions and pay resulted clashes with the KMC authorities and these tensions ultimately led to their eviction (Deepak Ratna Kansakar, personal communication). Currently, some of the informal recyclers employ door-to-door collection for wastes of higher market value like paper, plastic, glass and metals. Other recyclers especially women and children from slum dwellings collect different items typically of lower market value from onsite storage bins/containers and open storage space (Gautam, 2011). All informal waste collectors are at high health risk, as they do not wear any protective gloves, masks or clothes, and do not have any health insurance.

The problem of the urban waste management in Kathmandu valley lead to establishment of the Solid Waste Management and Resource Mobilization Centre (SWM \& RMC) as a central body to oversee waste management activities (Anderzen \& Blees, 2003). In 1990, the GTZ Solid Waste Management Project decreased their 
technical and financial assistance to the project and the responsibility to manage the Gokarna landfill site was transferred to the SWM \& RMC (Rana, 2003). Urbanization and rapid population increase in Kathmandu valley increased the volume of generated waste. Insufficient preparation of the Gokarna landfill site along with improper management of the waste resulted in the waste being scattered in the surrounding areas. Facing strong criticism from the public, the landfill was finally closed at the end of June 2000 (Anderzen \& Blees, 2003). With no alternative landfill site, $\mathrm{KMC}$ was again forced to dump waste along the Bagmati River (Anderzen \& Blees, 2003). The KMC has the responsibility for all solid waste management in Kathmandu city such as sweeping, collection, transportation, transfer stations and final disposal (Anderzen \& Blees, 2003). Looking at the characterization of waste for 2005 and 2009, it can be seen that most of the waste in Kathmandu city consists of organic waste (Fig. 2).

A

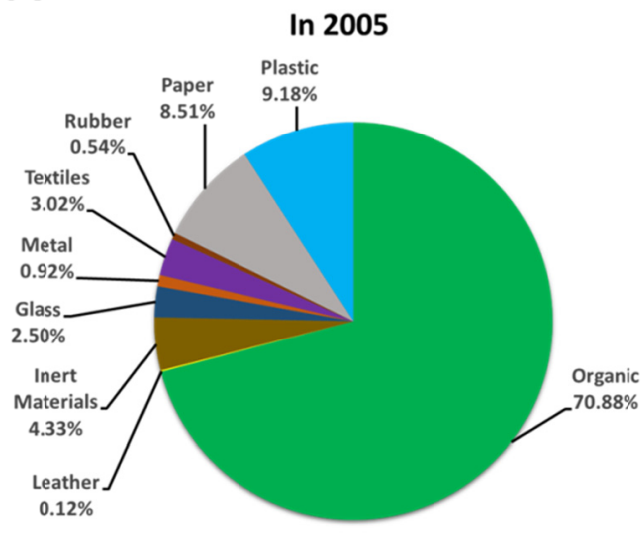

B

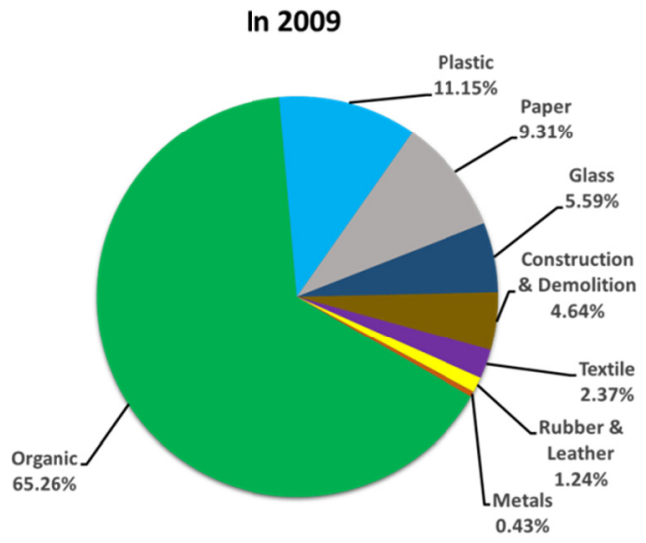

Figure 2. Characterization of waste in Kathmandu indicating large percentage of organic waste. Pie chart shows waste characterization for years 2005 (A) and 2009 (B) based on the data collected from Kathmandu Metropolitan City (KMC)

There are three ways of waste collection from households in the KMC (Alam, Chowdhury, Hasan, Karanjit, \& Shrestha, 2008): i) primary collection-refers to individual households placing raw solid waste into their personal refuse bins; ii) secondary collection-refers to collection of waste from the refuse bins or primary sites to the transfer stations or the final disposable site; and iii) direct collection-refers to collection of solid waste from households by collection vehicles of solid waste management organizations to final disposable site (Fig. 3).

\section{Present Waste Flow in Kathmandu City}

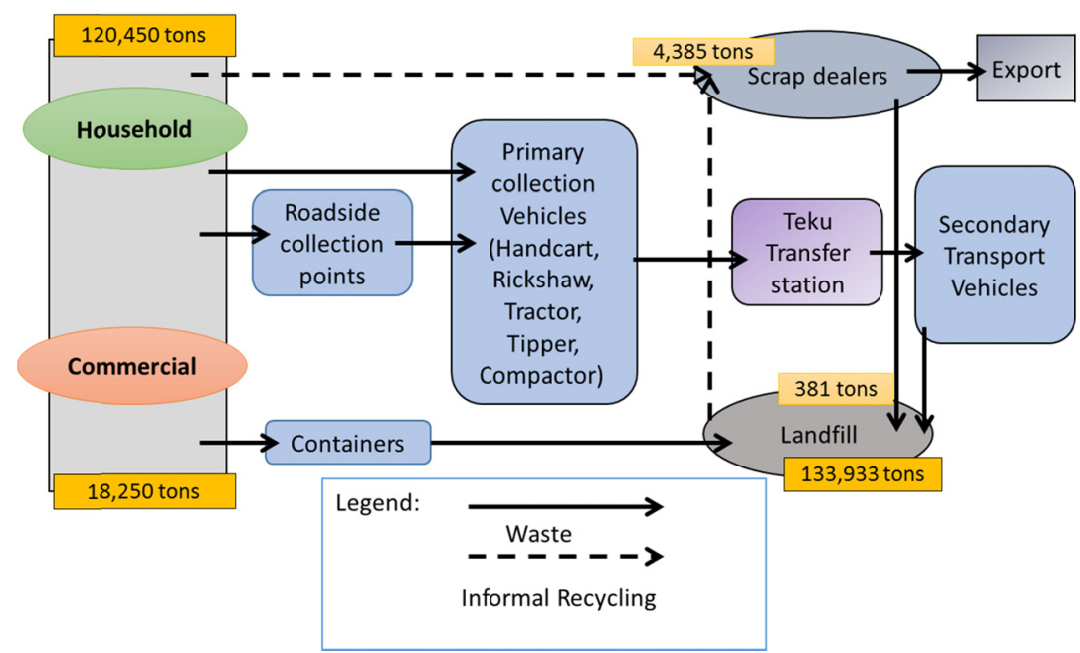

Figure 3. Present waste flow in Kathmandu city. The amount and flow of current waste from the source of production till the final disposal site is schematically presented 


\subsection{Objectives of the Current Study}

The main objectives of the study are i) to highlight the benefits of improving current landfill and the introduction of new sanitary landfill; ii) to analyze the potential environmental and socio-economic benefits of organic waste treatment and recovery; and iii) based on the integrated waste management approach, to propose different scenarios that include the recovery of organic materials and recycling of other materials such as cans, papers, glass at the transfer station while promoting the formalization of informal recyclers.

\section{Research Methodology}

The study proposes alternative scenarios to improve the current situation based on Life Cycle Assessment (LCA). LCA is an analytical tool for systematic evaluation of the environmental aspects of a product or service system through all stages of its life cycle (EEA, 1997). The International Organization for Standardization (ISO), a world-wide federation of national standards bodies, has specified this framework within the series ISO 14040 on LCA (EEA, 1997). In this research two (Objective and Scope Definition and Life Cycle Inventory) out of four stages of LCA were utilized, and most of the calculations were done based on Inventory Analysis as the purpose of the study was to analyze potential environmental benefits through alternative scenarios concerning current situation of KMC for the reduction of pollutants.

\subsection{Interview, Collection of Data, and Analysis}

\subsubsection{Structured Interviews}

Interviews were conducted with different government personnel from KMC, Solid Waste Management Technical Support Center, and staff from the NGOs (non-governmental organization) - Small Earth Nepal, and CBOs (community-based organization) - Women's Environment Preservation Committee (WEPCO, Nepal). Moreover, local people were randomly selected in the KMC and also at the landfill area of Sisdol for interviews (by the lead author, RKS) in order to know the current situation of Kathmandu's municipal solid waste. Interviews with KMC officials were conducted on the following dates: March $12^{\text {th }} 2013$, Rabindra Kuwar Rai, Senior Engineer, Solid Waste Management Section, KMC); March $13^{\text {th }}$ 2013, Deepak Ratna Kansakar, Civil Engineer and Site Manager of the Sisdol Landfill Site; and March $14^{\text {th }}$ 2013, Bishnu Thakali, President of WEPCO), with the questions related to waste shorting, participation of private organization in the sector, women role and participation in waste management and landfill management, etc., in KMC.

\subsubsection{Data Collection via NGOs and Online Sources}

The research included visits to various private organizations in Kathmandu city for the collection of data and relevant facts and information related to the waste in the city. In addition, a literature survey was carried out using different online databases and analysis of research papers on the topic.

\subsubsection{Data Analysis by LCA}

The collected data was analyzed using an integrated waste management approach in the modeling and subsequently LCA was used to evaluate the potential environmental impacts.

\subsection{Scenarios Design}

The scenarios design for KMC waste management is based on the current situation where almost all of the waste is landfilled, and where the present landfill has reached its capacity. The report by (ADB 2013) and the data collected by KMC indicated that more than $60 \%$ of total municipal waste is organic and that it can be reused and recycled. The government department for Nepal's energy strategy plan intends to promote clean energy in the form of bio-gas over other renewable energy sources. Thus, based on the above information, the scenarios were developed.

Scenario 1 .

\begin{tabular}{cl}
\hline Collection Type & Frequency \\
\hline Kerbside: Mixed collection & Once in a week \\
Treatment type & Low recycling, Most of the waste is landfilled \\
Treatment rate & Recycling $=3.44 \%$, Landfill $=96.56 \%$ \\
Recovery & Paper $=13 \%$, Glass $=29.7 \%$, Plastic $=20.3 \%$ \\
\hline
\end{tabular}




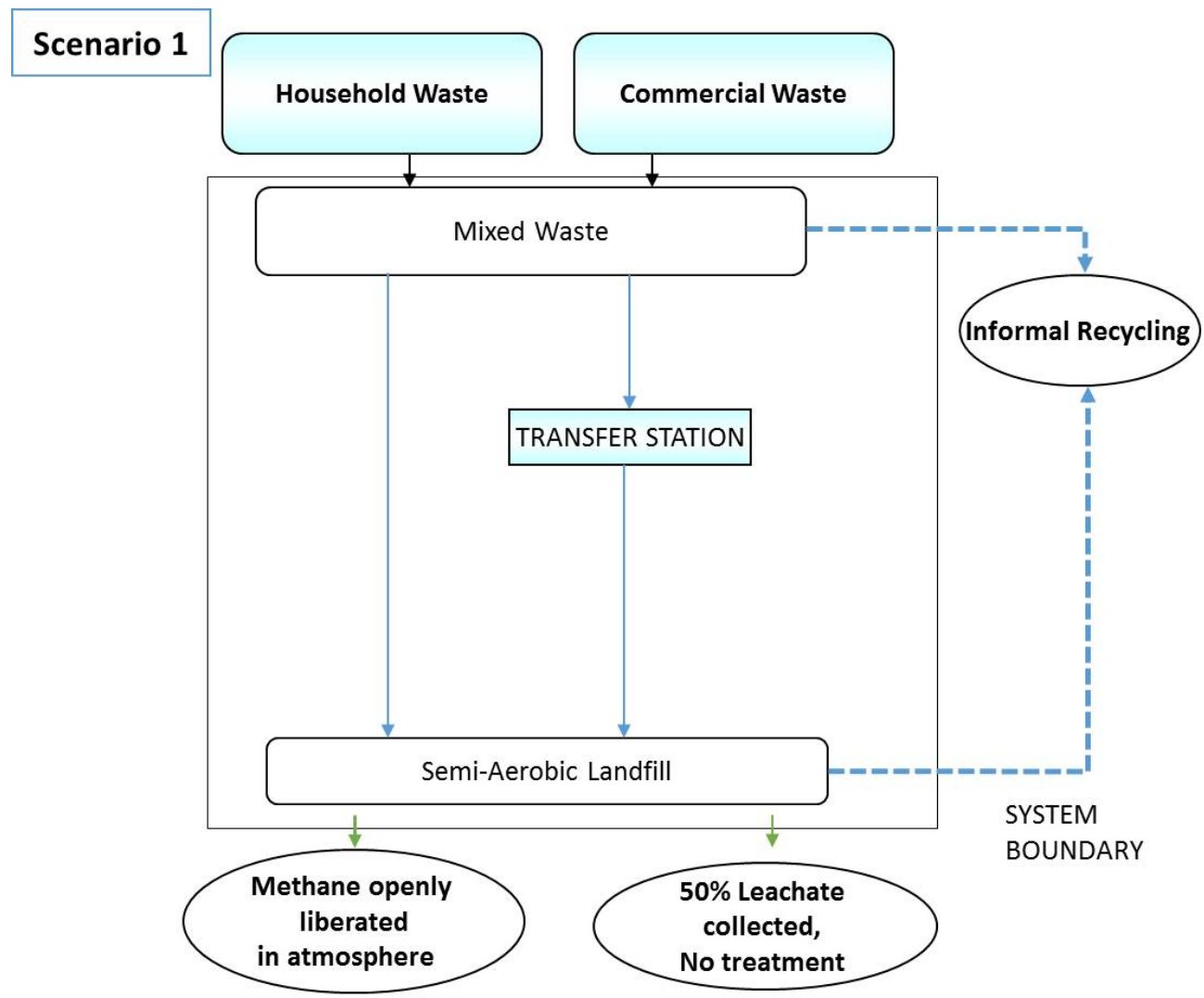

Figure 4. Scenario 1: Baseline scenario. The current waste flow from the source of production to final disposal (landfill) is shown

Scenario 1 is based on the present situation in Kathmandu city where almost all the waste from the household and commercial sector is taken to the landfill directly or indirectly (Fig. 4). Assuming, part of the waste that comes from households and the commercial sector is taken to the transfer station (Teku) and then to the landfill site while some waste is taken directly to the landfill site (Fig. 3). Informal recyclers collect some material door to door, and the material collected (paper, plastic and glass) reaches the overall recycling ratio of $3.44 \%$ as shown in Table 1. Collection is done twice a week at kerbside. The recovery of material is limited. For example, paper $=13.16 \mathrm{~kg} /$ household $/$ year, glass $=30 \mathrm{~kg} /$ household $/$ year, and plastic $=20.31 \mathrm{~kg} /$ household $/$ year. The waste is collected once a week at kerbside. If the informal recycling is not done by the informal recycler, all the waste will go to landfill increasing the amount of incoming waste and decreasing the life of the landfill.

Scenario 2.

\begin{tabular}{cl}
\hline Collection Type & Frequency \\
\hline Kerbside: Mixed collection & Once in a week \\
Treatment type & Low recycling, Most of the waste is landfilled, \\
& Methane is $100 \%$ collected, Leachate is \\
Treatment rate & $60 \%$ treated \\
Recovery & Recycling $=3.44 \%$, Landfill $=96.56 \%$ \\
\hline
\end{tabular}




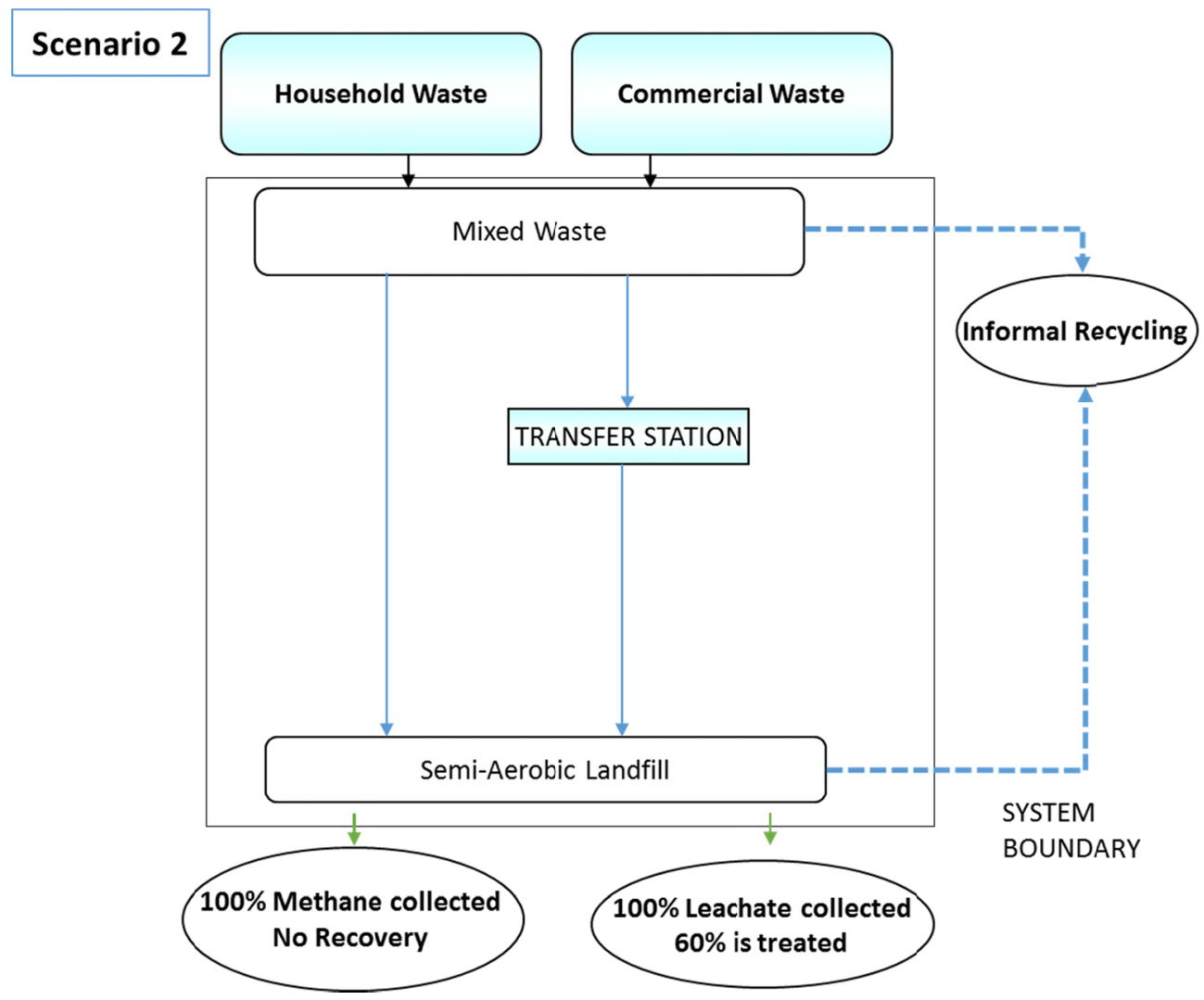

Figure 5. Scenario 2: Improvement at landfill. The figure shows the improvement at the landfill where the liberated methane gas at landfill is collected and of total leachate produced $60 \%$ is treated

Scenario 2 indicates the waste management condition in Kathmandu city assuming the landfill site is improved (Fig. 5). In this case, methane gas, liberated openly into the atmosphere is $100 \%$ collected and burnt. The leachate is also $100 \%$ collected, of which $60 \%$ is treated before discharge into the environment. Other conditions are the same as in the Scenario 1. The waste is collected twice a week at the kerbside.

Scenario 3.

\begin{tabular}{cl}
\hline Collection Type & Frequency \\
\hline $\begin{array}{c}\text { Kerbside: Organic/Inorganic } \\
\text { collection }\end{array}$ & Both (Organic \& Inorganic): Three times a week \\
Treatment type & $\begin{array}{l}\text { Recycling, Composting, Bio-gasification \& Landfill } \\
\text { Recycling }=12.78 \%,\end{array}$ \\
Treatment rate & Landfill $=80.91 \%$, Combusted $=6.31$, Organic waste $\quad(40 \%$ of commercial \\
& waste=Bio-gasification), (20\% of Household waste $=$ compost $)$ \\
& Household: Paper $=26 \%$, Glass $=60 \%$, Plastic $=40 \%$ \\
Recovery & Commercial: All $60 \%$ \\
\hline
\end{tabular}




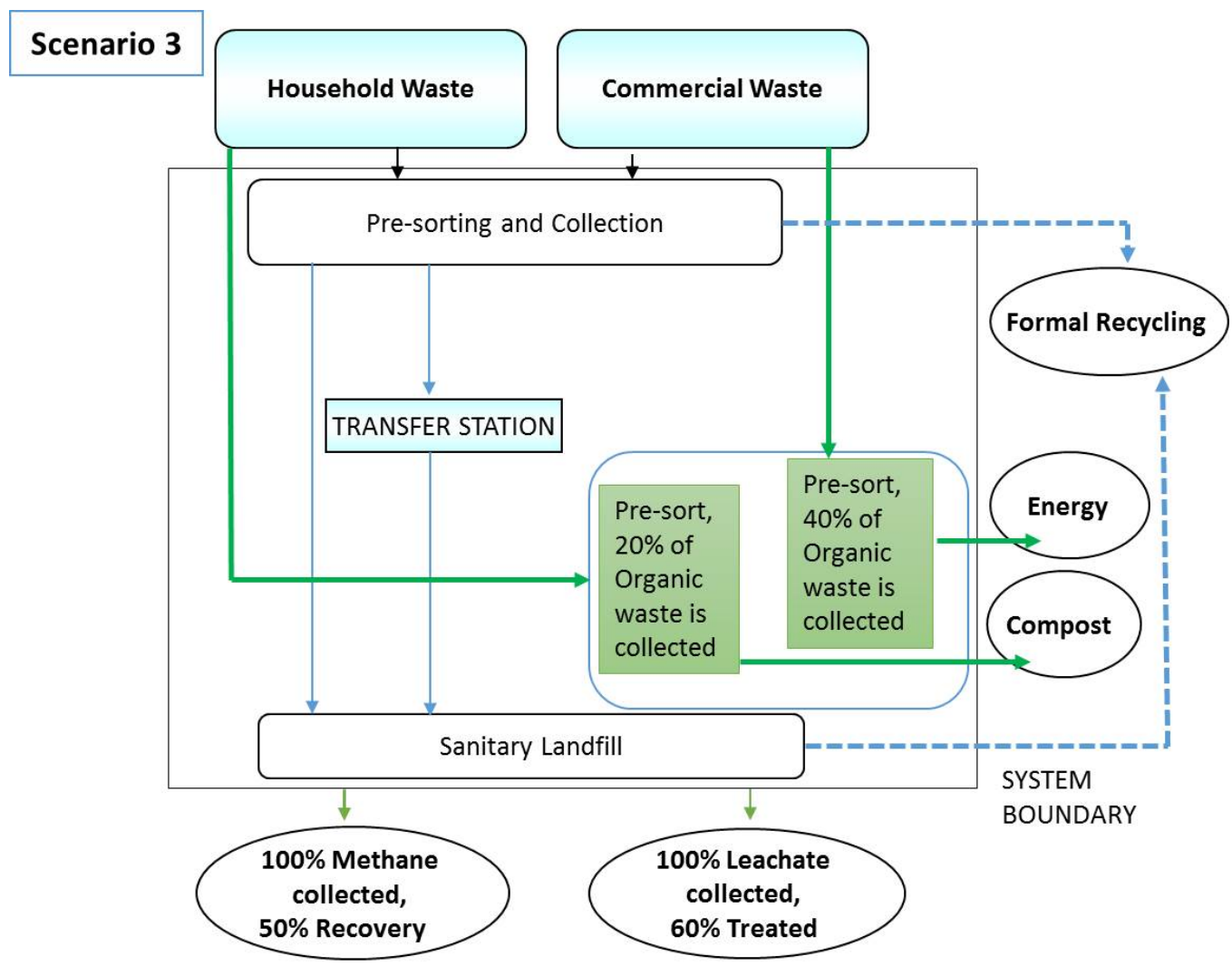

Figure 6. Scenario 3: Introduction of sanitary landfill formalization of informal recyclers, biological treatment of organic waste. The figure shows the formalization of informal recyclers and introduction of sanitary landfill site.

The treatment of organic waste into compost and bio gasification is also shown

In scenario 3, it is assumed that the local government allocates a specific day once a week for local people to place recyclable materials at allocated spots. The informal recyclers are formalized by the government who then collect those materials for recycling. This assumes that this initiative will double the recycling level from household which includes $14 \%$ of paper $(26.31 \%), 19 \%$ of glass $(60 \mathrm{~kg} /$ household/year) and $13.2 \%$ of plastic (40.62 kg/household/year) (Fig. 6). The recyclable material from the commercial sector is also recycled up to $60 \%$ which includes paper (2300 tons per year), glass (548 tons per year) and plastic (1445 tons per year). It is assumed that NGOs and International NGOs encourage people to compost their organic waste. The NGO's and the government also encourage the commercial sector to develop bio-gasification to produce electricity for supply to the city. Based on these two facts the ratio for composting and bio-gasification is determined. Out of total organic waste from households $20 \%$ of organic waste is collected which is equivalent to 14456 tons per year and is used for making compost. From the total organic waste from the commercial sector, $40 \%$ is collected which is equivalent to 2920 tons per year and is used for bio-gasification. The organic fertilizer produced from the compost and the bio-gasification plant is $100 \%$ marketable and creating a source of income. The energy released from the bio-gas plant is utilized for diverse purposes such as cooking, electricity, heating, etc. The waste collection is done 3 times a week at kerbside and to increase the recycling efficiency the waste is sorted at source. The methane gas collection is $100 \%$ of which $50 \%$ is recovered as energy. Similarly, the leachate collection is also $100 \%$, out of which $60 \%$ is treated before being released into the environment. 
Scenario 4

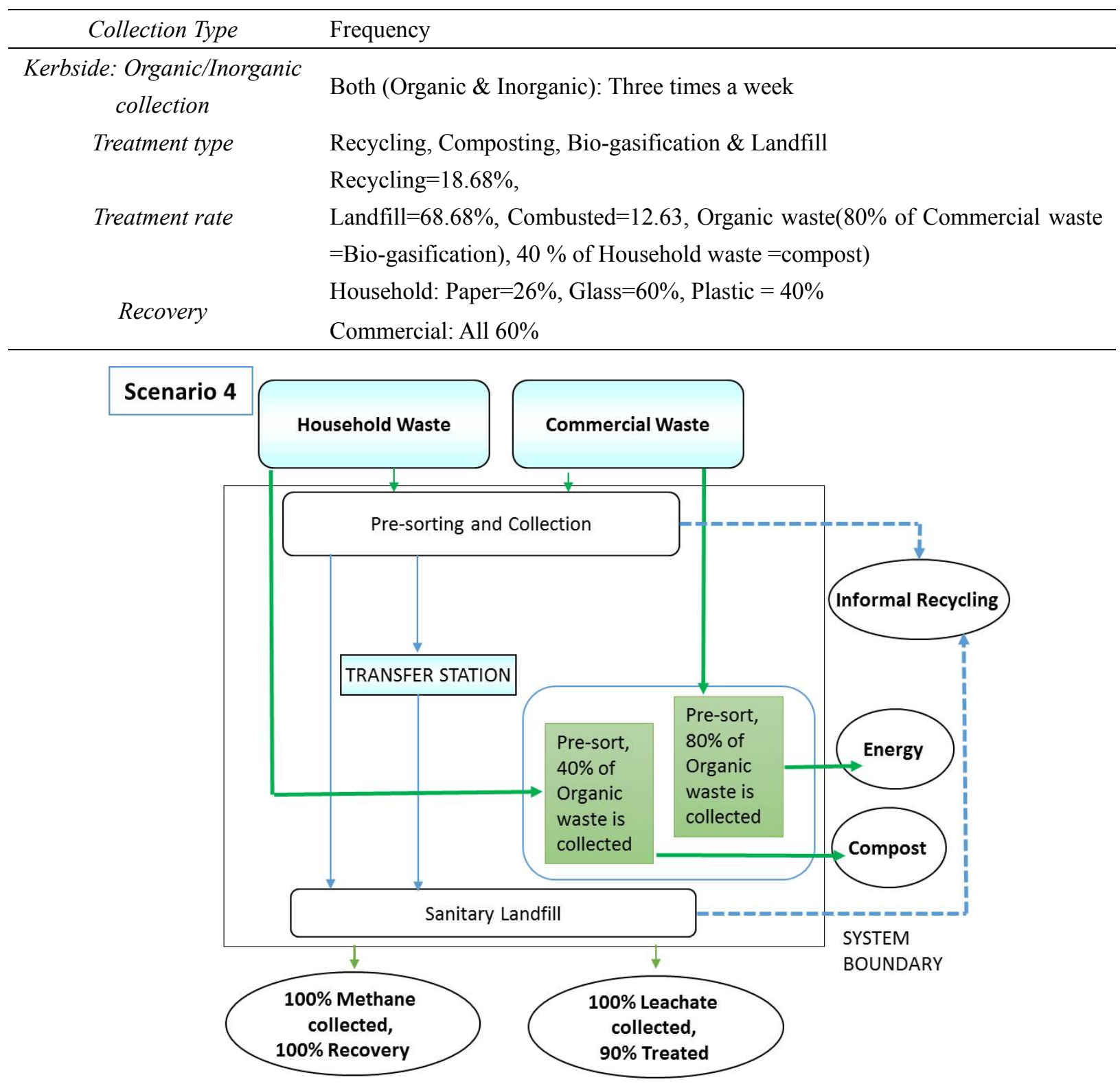

Figure 7. Scenario 4: Energy recovery at landfill. The figure shows $100 \%$ energy recovered from methane produced and collected at landfill. It also shows $95 \%$ of leachate is treated out of total leachate produced and collected at landfill

Scenario 4 has the same recycling efficiency of recyclable materials from households and the commercial sector as the scenario 3 (Fig. 7). Out of total organic waste from households $40 \%$ of the organic waste is collected, which is equivalent to 28931 tons per year and is used for making compost. From the total organic waste from the commercial sector, $80 \%$ is collected, which is equivalent to 5840 tons per year and is used for bio-gasification. The methane gas collection is $100 \%$ and the energy recovered from it is also $100 \%$. Similarly, $100 \%$ of leachate is also collected and $95 \%$ of it is treated before being released into the environment. Waste is collected 3 times a week at kerbside and the waste from households and the commercial sector are sorted at the source.

\subsection{Research Scope and Limitations}

\subsubsection{Medical Waste}

There are incinerators in most hospitals in Kathmandu city for the management of medical waste. However, due 
to high operating costs the incinerators are not used. It was found that the medical waste is mixed with the municipal solid waste and taken to the Sisdol landfill site. During scenario development we consider that medical waste is not mixed with the municipal solid waste.

\subsubsection{Compost and Bio-gas}

Some of the organizations like the WEPCO in Kathmandu city are very active in the management of solid waste. WEPCO is working on community composting, vermin-composting and bio-gas production from organic waste especially vegetables on very small scale of 4 tons per day. They are also helping households around the city to make compost out of organic waste. Furthermore, they are now providing support in establishing bio-gas plants in several schools and hotels. In this research, compost and a bio-gas plant are not taken into account as it was very difficult to get information on these aspects and also the compost production is at a very small scale.

\subsubsection{Waste from Outside the Kathmandu City to Landfill}

Some waste from neighboring cities such as Bhaktapur and Kritipur also comes to the landfill site, however there is no data detailing the exact amount. In the research, all the waste from Kathmandu city is considered to have been taken to the Sisdol landfill site.

\subsubsection{Waste Dumped on Riverbanks}

At present some people dump their waste in the Bagmati River in the city, which is already polluted. The amount of waste being dumped in the river is small compared to the past according to local people residing in Kathmandu city but the exact amount dumped in the river is unknown. Therefore, waste dumped on the river bank is not considered in this research.

\section{Results}

\subsection{Waste Management and Landfill}

The KMC collects most of the city waste, however, at present numerous private organizations are also involved in waste collection. The number of private organizations working in the sector has increased rapidly and is estimated to increase more in coming year (personal interview). To date there are 18 private organizations involved in the management of waste in KMC (personal interview). Furthermore, many NGOs, CBOs, and youth clubs are involved in the collection of waste (personal interview). Currently, KMC has only a single landfill which is located in Sisdol of the Okharpauwa Village Development Committee (VDC). A waste transfer station that lies between the waste collectors who unload the collected waste prior to final destination at Sisdol is around $28 \mathrm{~km}$ from the landfill site (Japan International Cooperation Agency, JICA, 2007). The landfill was built for a short period of 3 years through the technical and financial support of JICA but it was extended till 2012 as there was no other option for final disposal (personal interview) Unfortunately, KMC still uses the present landfill site as its final disposal site (the proposed sanitary landfill site, the Bancharedada) is yet to be commissioned. Reservation of required area of land for the proposed Bancharedada landfill has been undertaken by the government, however it is estimated that it will take around 3 years to complete the sanitary landfill (The Himalayan Times, 2013). Thus, the current situation of overload and increasing waste generation coupled with lack of proper management has turned the Sisdol landfill into a dumping site.

The addressed waste management problems are common in many cities of developing countries like India and Bangladesh. As stated the focus of the problem is on three main issues i) engaging informal recyclers, ii) composting and bio-gasification of organic waste, and iii) appropriate management of sanitary landfill. The informal recyclers were not allowed to work at the transfer station, as they were unable to reach common ground with government during negotiations. The government should involve the informal recyclers formally in the sorting, collection and recycling of materials in a well-managed material recovery facility to help increase the collection rate of recyclable and reusable materials from municipal solid waste. The informal recyclers can earn a higher income once they discover the value of a salaried job that, in turn, will motivate them to work harder. The informal recyclers should be provided with the following benefits as mentioned in the book, "Integrated Solid Waste Management: a Life Cycle Inventory" (McDougall, 2003). Those benefits as mentioned are as follows - Improved working conditions so that they do not have to sort materials in the landfill itself, health insurance, and modest affordable accommodation for informal recyclers and their families paid for out of the money they earn for separating recyclable materials.

These measures can bring many people to work as formal recyclers and give them the opportunity to increase their income by pooling recyclable materials that can be sold in bulk. There is a good example of formalization of informal recyclers in Madras (India) based around a government organization called EXNORA (McDougall, 2003) and appoint informal recyclers from the streets who then take care of street sweeping, collecting MSW, 
sorting of recyclables and disposing of the remainder of the waste at the nearest municipal transfer site and also collect organic waste separately in some streets and use it for making compost (McDougall, 2003).

The Mechanical Biological Treatment (MBT) facility introduced in Europe failed due to lack of organic waste sorting at source (Raninger, Rundong \& Lei, 2007). Similarly, GTZ introduced MBT-based compost plant in $\mathrm{KMC}$, but which was closed due to lack of sorting at source as in Europe. The only landfill site, the Sisdol landfill site is already at maximum capacity and has now turned into a dumping site due to improper management of the landfill site, which indicates a need for an alternative sanitary landfill site. The government should also keep in mind requirements for the smooth operation of the alternative sanitary landfill site once it comes into operation. This research will address the above problems and will try to solve these issues through an integrated waste management approach.

\subsection{Scenario Development Reveals the Importance of Sorting and Recycling}

For the evaluation of the environment we used four indicators Global Warming Potential (GWP), Biological Oxygen Demand (BOD), final disposal of waste, and recovery of material and energy recovery.

\section{GHG Emission}

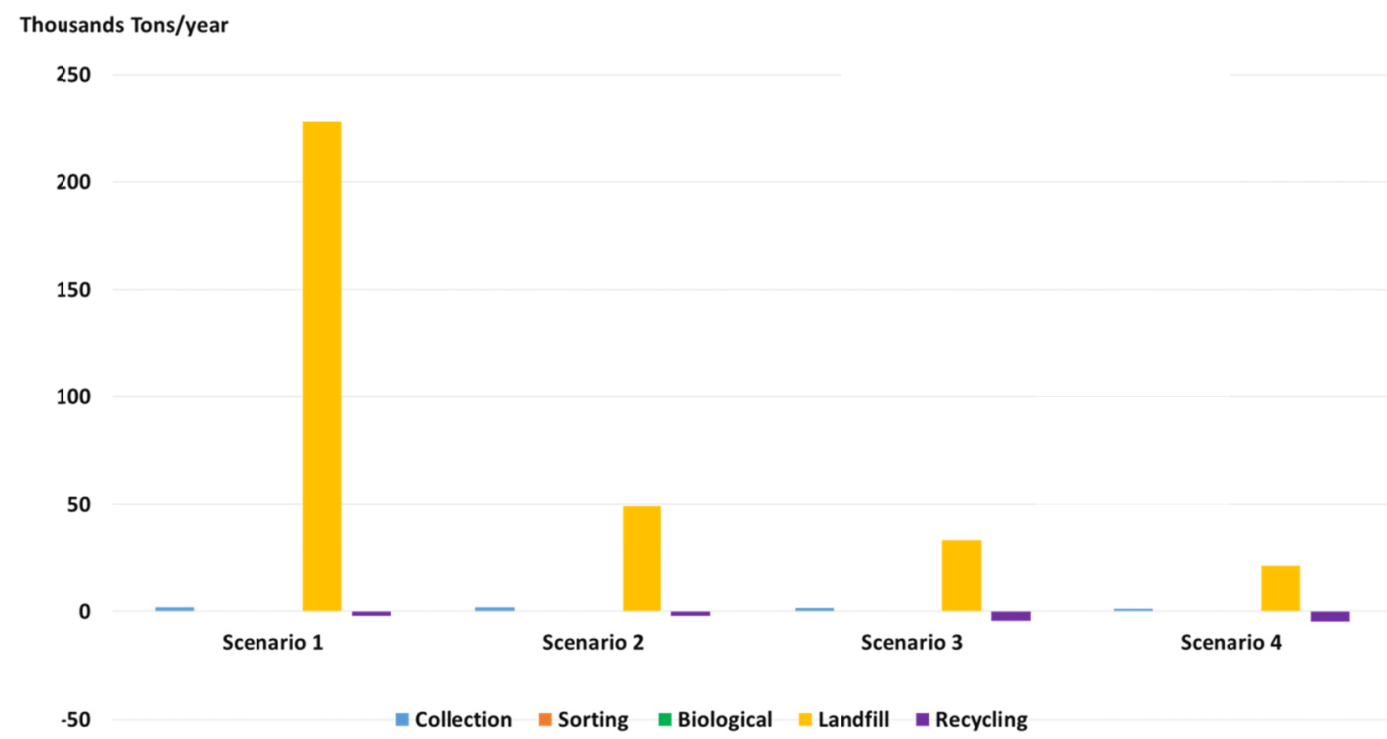

Figure 8. GHG emission from collection till the final disposal of the municipal solid waste. The figure shows the amount of GHG emitted in every scenario from the cradle to grave

\subsubsection{GWP}

From Figure 8, we can see that GWP is very high in the $1^{\text {st }}$ scenario at landfill, which is the current situation due to methane gas released into the environment. In the $2^{\text {nd }}$ scenario, the methane gas collected at the landfill is burnt instead of being liberated openly into the atmosphere. This helps to decrease the GWP drastically at landfill from 228,410 tons per year to 49,513 tons per year. Due to more recycling and recovery of organic material in scenario 3, the total GWP decreases and reaches 30894 tons per year. Finally, when there is $100 \%$ recovery of methane in scenario 4, the total amount of GWP reaches 17890 tons per year, which means the contribution to the total GWP is less compared to the present situation.

\subsubsection{BOD}

In the current $\left(1^{\text {st }}\right)$ scenario of Figure 9, the BOD level is 47 tons per year at landfill and 3 tons per year during recycling, which is very high and indicates the presence of a huge amount of organic pollutants. When the collected methane at landfill is burnt and the collected leachate is treated up to $60 \%$ in scenario 2, the BOD level decreases to 19 tons per year at landfill and remains same for recycling. More organic recovery is done in scenario 3, which helps the BOD level to decrease to 15 tons per year. The BOD from biological treatment is 6 tons per year due to recycling of paper which requires more water. In scenario 4, the BOD level reaches 3 tons per year at landfill which indicates there is less organic pollutant and it is achieved due to $100 \%$ recovery of methane gas and 95\% treatment of leachate collected at the landfill. The BOD from recycling is 6 tons per year and the biological treatment is 2 tons per year. This shows that there are less organic pollutants in scenario 4 
compared to all other scenarios, which indicates that scenario 4 provides a much safer and cleaner environment.

BOD

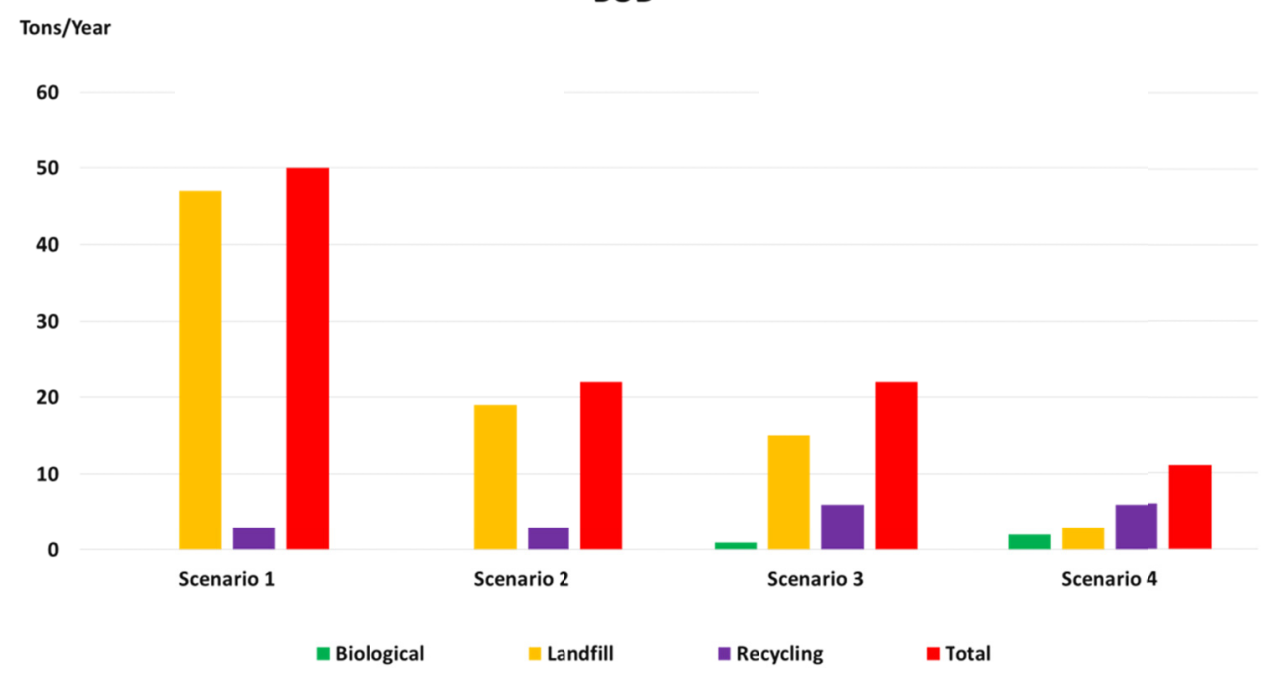

Figure 9. BOD emission from collection till the final disposal of the municipal solid waste. The figure shows the amount of BOD emitted from the municipal solid waste in every scenario during biological treatment, recycling of the material and at the landfill

\subsubsection{Final Disposal of Waste}

In the current $\left(1^{\text {st }}\right)$ scenario of Figure 10, the volume of waste coming to the landfill site is 128,628 tons per year, which takes up a large volume in the landfill as compared to scenario 3 and 4. More waste coming to landfill indicates that its life will decrease faster due to the huge volume of the waste. The volume of the waste scenario 1 and 2 is almost same representing 128,628 tons and 128,779 tons per year respectively. This is due to the treatment of up to $60 \%$ of the leachate at the landfill in scenario 2 , which produces some solid material after treatment that goes to landfill further increasing the volume of waste. In scenario 1, there is no treatment of the leachate but it is only collected in the leachate pond. In the scenario 3 , the volume of the waste decreases to 100,715 tons per year due to more recycling of recyclable materials and recovery of organic materials. Furthermore, the volume of waste decreases to 82,224 tons in scenario 4 . This is due to $90 \%$ of leachate treatment and $100 \%$ of methane recovery at the landfill.

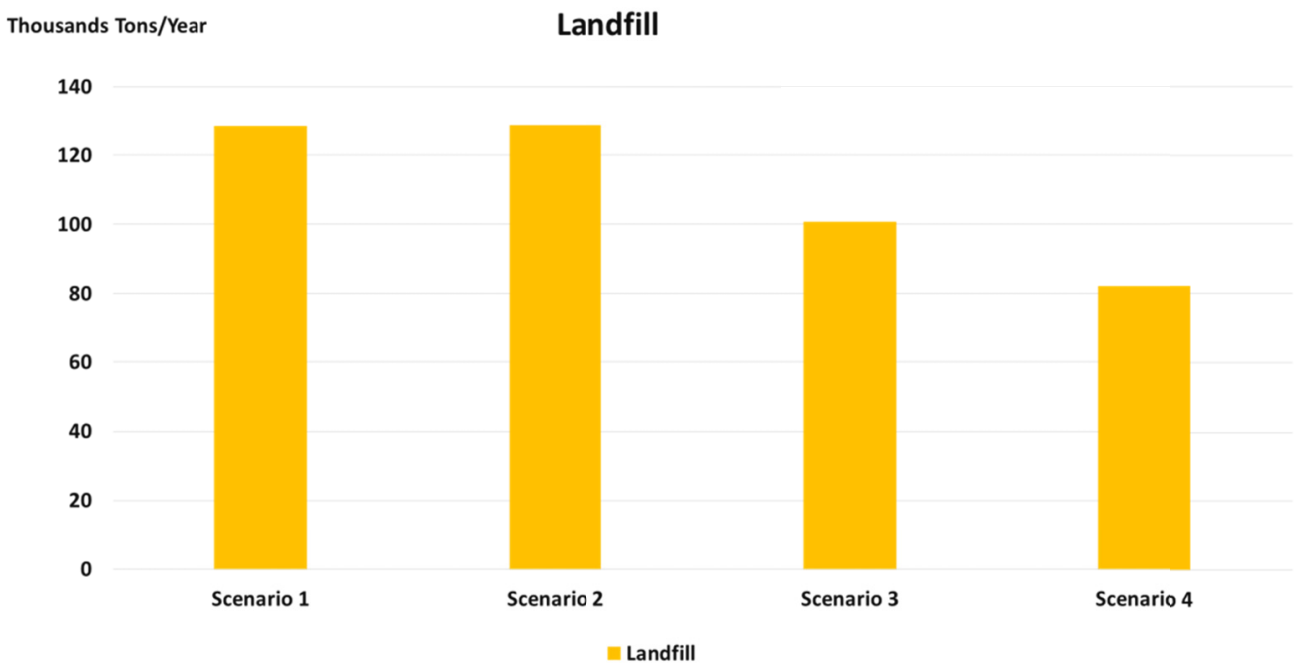

Figure 10. Total waste at landfill. The figure shows the total amount of waste getting dumped into landfill from 
the KMC

\subsubsection{Recovery of Materials}

With the introduction of a specific collection day by the government and the cooperation of householders it is possible to double or triple the amount of recyclable waste according to the level of cooperation as shown in Figure 11. There are two major benefits in this case i) decreasing the amount of waste going to landfill i.e. enhancing the life of the landfill site, and ii) decrease in the use of virgin materials.

\section{Recovery of Material}

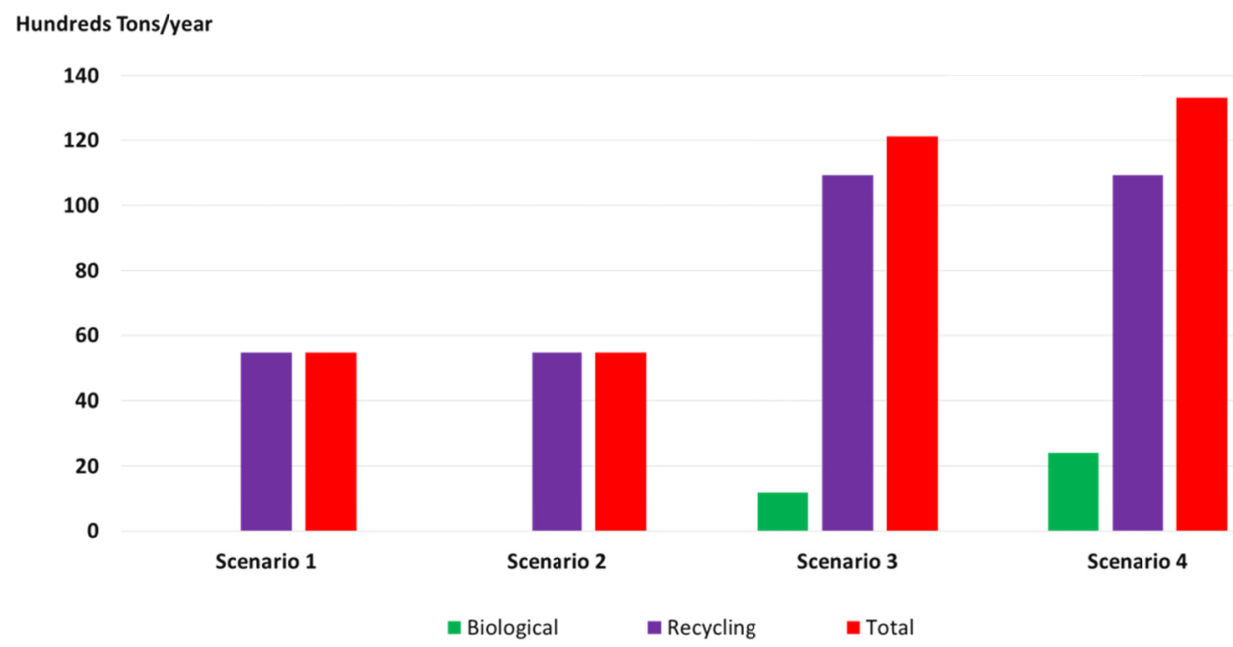

Figure 11. Recovery of material. The figure shows the total amount of material recovered during recycling and biological treatment

\subsubsection{Amount of Energy Generated}

In the current $\left(1^{\text {st }}\right)$ and $2^{\text {nd }}$ scenarios of Figure 12, there is no energy generation. The small amount of energy generated in the $3^{\text {rd }}$ scenario amounts to $15,822,886 \mathrm{kWh}$. The energy generated in the $4^{\text {th }}$ scenario is $25,281,171$ $\mathrm{kWh}$. The $4^{\text {th }}$ scenario has huge potential for energy generation compared to all other scenarios.

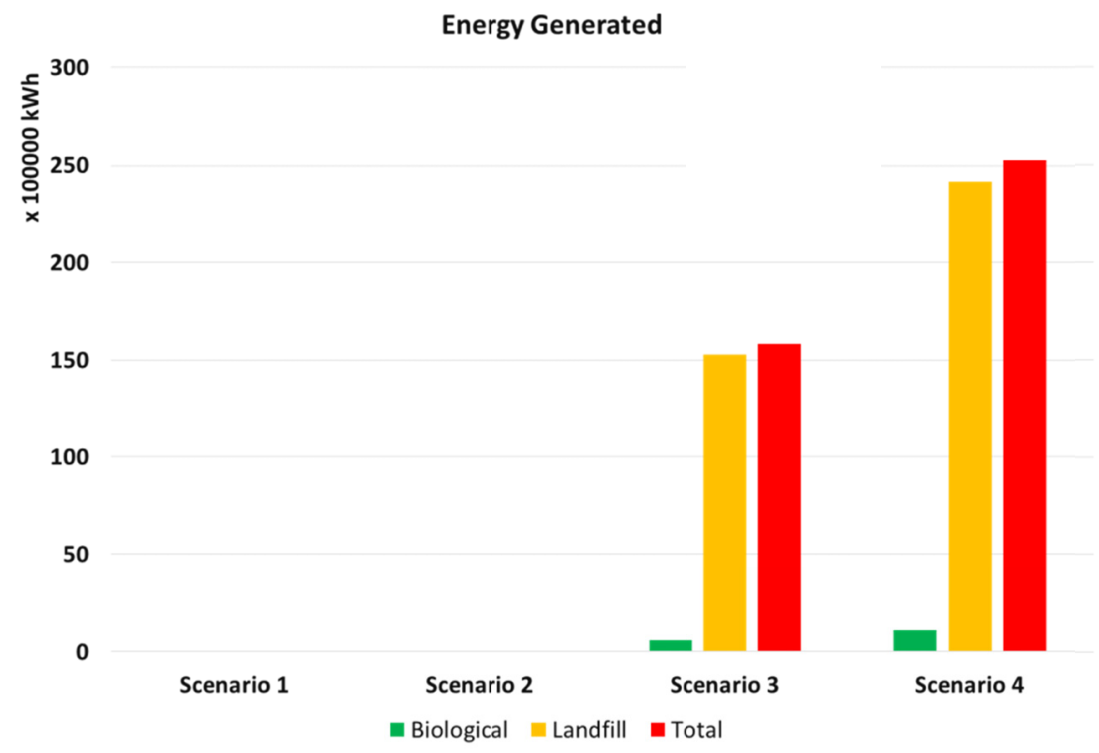

Figure 12. The amount of energy generated. The figure shows the amount of electricity that can be produced in different scenarios 


\section{Discussion}

In scenario 1 and 2, most of the waste is taken to the landfill with very little recovery of material being done by the informal recyclers. In scenario 1, the methane gas at the landfill is liberated in the atmosphere and there is no proper treatment of the leachate produced. In scenario 2, the generated methane gas is collected and burnt .The leachate is also $100 \%$ collected of which $60 \%$ is treated. In scenario 3, it is assumed that the local government works towards the formalization of informal recyclers and encourages people to separate their recyclable waste. This helps to double recycling compared to scenarios 1 and 2 for households. The participation of NGOs and CBOs in Khulna City ( $3^{\text {rd }}$ largest metropolitan city in Bangladesh) has improved the overall MSW management system especially the waste collection process from source and motivated the residents to store the waste properly and to keep the premises clean (Ahsan, Alamgir, Imteaz, Daud \& Islam, 2012). Similarly, in the scenario, it is also assumed that the government, NGOs and INGOs encourage people to compost and bio-gasify for fertilizer and electricity generation to meet the electricity demands of the city. Introduction of organic waste recovery in scenario 3 at lower levels coupled with recycling of inorganic waste with $60 \%$ treatment of total leachate leads to environmental benefits at much higher levels as shown in Figures 8 to 11. Likewise, strong collaboration with all the stakeholders and recovery of $100 \%$ of the total methane and $90 \%$ of total leachate treatment leads to even further increases in benefits in scenario 4 as shown in Figures 8 to 11 . The stakeholder-based SWOT analysis for successful municipal solid waste management in Lucknow, India is a good example (Srivastava, Kulshreshtha, Mohanty, Pushpangadan \& Singh, 2005). Figure 12 also shows that scenarios 3 and 4 have potential for net energy generation.

\section{Conclusions}

In this research we try to identify the potential environmental and socio-economic benefits of introducing organic waste recovery coupled with the expansion of recycling of inorganic waste through cooperation with the informal sector and establishment of a well-managed sanitary landfill. We used Kathmandu city as a model case. The LCA was used to evaluate the potential environmental impacts. We propose four different scenarios based on feasible options that focus on organic recovery and informal recycling at the transfer station prior to movement to the landfill site. The scenarios were evaluated in terms of GWP, BOD, final disposal waste, and recycling levels and energy recovery. Our results show that the introduction of bio-gasification of commercial waste and composting of household waste coupled with enhanced recycling and sanitary landfill will result in greater environmental plus socio-economic benefits. From our results, scenarios 3 and 4 provided the highest environmental and socio-economic benefits. However in order to achieve this, the cooperation of all stakeholders is crucial. In this sense campaigns for $3 \mathrm{R}$ 's awareness must be promoted and enhanced. At present the government is planning to construct a sanitary landfill (Bancharedanda Landfill) for which scenario 4 may be the best and most workable option as it solves all the present problems. Moreover, it also has a huge potential for energy generation that can help to meet the present electricity demand of KMC to some extent. Therefore, it is our belief that the government should be aware of the need to implement waste management on the basis of scenario 4 while constructing the new sanitary landfill site.

\section{Acknowledgments}

Authors gratefully acknowledge financial support from the Environmental Diplomatic Leader (EDL) Program at the University of Tsukuba. RR also appreciates the Organization for Educational Initiatives (OEI), University of Tsukuba HQ, for research fund.

\section{References}

ADB. (2013). Solid Waste Management in Nepal: Current Status and Policy Recommendations. Mandaluyong City, Philipines.

Ahsan, A., Alamgir, M., Imteaz, M., Daud, N. N., \& Islam R. (2012). Role of NGOs and CBOs in Waste Management. Iranian Journal of Public Health, 41(6), 27-38.

Alam, R., Chowdhury, M. A. I., Hasan, G. M. J., Karanjit, B., \& Shrestha, L. R. (2008). Generation, storage, collection and transportation of municipal solid waste-A case study in the city of Kathmandu, capital of Nepal. Waste Management, 28(6), 1088-1097. http://dx.doi.org/10.1016/j.wasman.2006.12.024

Anderzen, C., \& Blees V. (2003). Solid waste management in the city of Kathmandu, Nepal; Evaluation of the Vaxjo risk assessment model applied on Gokarna landfill site. Program of Environmental Engineering, Kalmar University, Thesis. 
Dangi, M. B., Pretz, C. R., Urynowicz, M. A., Gerow, K. G., \& Reddy, J. M. (2011). Municipal solid waste generation in Kathmandu, Nepal. Journal of Environmental Management, 92(1), 240-249. http://dx.doi.org/10.1016/j.jenvman.2010.09.005

Eguchi, A., Isobe, T., Ramu, K., Tue, M. N., Sudaryanto, A., Devanathan, G., Viet, H.P., Tana, S. R., Takahashi, S., Subramanian, A., \& Tanabe, S. (2013). Soil contamination by brominated flame retardants in open waste dumping sites in Asian developing countries. Chemosphere, 90(9), 2365-2371. http://dx.doi.org/10.1016/j.chemosphere.2012.10.027

European Environment Agency (1997). Life cycle assessment (LCA). A guide to approaches, experiences and information sources. Environmental Issues Series No. 6, EU.

Gautam, P. (2011). Social life cycle assessment of solid waste management in Kathmandu City Nepal.

Guerrero, L. A., Maas, G., \& Hogland, W. (2013). Solid waste management challenges for cities in developing countries. Waste Management, 33(1), 220-232. http://dx.doi.org/10.1016/j.wasman.2012.09.008

Japan International Cooperation Agency (JICA). (2007). Improvement Case of Landfill Site by the Fukuoka Method. Improvement Work at Sisdol Short-term Landfill in Nepal.

Joshi, J. (2013). Why Waste! Scope Nepal Environment, Peace, Security and Social Justice Center 3-1.

Marshall, R. E., \& Farahbakhsh, K. (2012). Systems approaches to integrated solid waste management in developing countries. Waste Management, 33(4), 988-1003. http://dx.doi.org/10.1016/j.wasman.2012.12.023

McDougall, F., White P., Franke, M., \& Hindle, P. (2003). Integrated Solid Waste Management: A Life Cycle Inventory (2nd ed.). United States, USA: Blackwell Science.

Rana, S. (2013). Solid waste management for Kathmandu Metropolitan City. Retrieved July 20, 2014, from http://hamrodayitwa.org/docs/reports/SOLID_WASTE_MANAGEMENT_FOR_KATHMANDU_METRO POLITAN_CITY_by_Saurav_Rana.pdf

Raninger, B., Rundong, L., \& Lei, F. (2007). Activities to apply the European experience on anaerobic digestion of bioorganic municipal waste from source separation in China. The Sino-German RRU-BMW project in Shenyang.

Sapkota, A. (2013). Managing Municipal Solid Waste in Kathmandu. Observation and Policy Recommendation.

Srivastava, P. K., Kulshreshtha, K., Mohanty, C. S., Pushpangadan, P., \& Singh, A. (2005). Stakeholder-based SWOT analysis for successful municipal solid waste management solid waste management in Lucknow, India._Waste Management, 25(5), 531-537. http://dx.doi.org/10.1016/j.wasman.2004.08.010

The Himalayan Times. (2013, September 17). Government to repay locals for new landfill site. Retrieved September 25, 2013, from $\mathrm{http} / /$ thehimalayantimes.com/fullTodays.php?headline $=$ Country\%27s + largest + landfill + site + in + the + makin g\&NewsID $=391177$

UNEP. (2013). UNEP Global Environmental Alert Service (GEAS). Taking the pulse of the planet; connecting service with policy.

UNEP. (n. d.). Life Cycle Assessment. Retrieved July 15, 2014, from http://www.unep.org/resourceefficiency/Consumption/StandardsandLabels/MeasuringSustainability/LifeCy cleAssessment/tabid/101348/Default.aspx

Yabar, H., Hara, K., Uwasu, M., Yamaguchi, Y., \& Zhang, H. (2009). Integrated resource management towards a sustainable Asia: Policy and strategy evolution in Japan and China. International Journal of $\begin{array}{lllll}\text { Environmental Technology and 239-256. } & \text { Management, 11(4), }\end{array}$ http://dx.doi.org/10.1504/IJETM.2009.027609

\section{Copyrights}

Copyright for this article is retained by the author(s), with first publication rights granted to the journal.

This is an open-access article distributed under the terms and conditions of the Creative Commons Attribution license (http://creativecommons.org/licenses/by/3.0/). 